\title{
Interlanguage pragmatics in a service encounter: diagnosing how Spanish learners of English for the Tourism Industry inform tourists at a visitor centre
}

\author{
A pragmática da interlíngua nos encontros de serviço: \\ diagnosticando como espanhóis estudantes de inglês para a Indústria do Turismo \\ informam os turistas em um centro de visitantes
}

Manuel Padilla Cruz

University of Seville - Seville, Spain

Nuria Martínez López

European University Sports Association - Seville, Spain

\begin{abstract}
This study explores the behaviour of (pre-)intermediate Spanish learners of English for the Tourism Industry at the transactional phase of a service encounter wherein they have to carry out one of the tasks for which they are trained: giving information at a tourist visitor centre. More specifically, this study analyses (i) the strategies wherewith they dispense tourist information, and (ii) how they attend to relational aspects during the encounter or manage rapport with tourists through such strategies and the information dispensed. Thus, this study purports to shed light onto learners' skills prior to instruction in an area which, although usually included in ESP textbooks, seems to have been overlooked by practitioners in interlanguage pragmatics. The preliminary need diagnosis that this paper makes may be the foundation upon which pedagogical intervention may subsequently be designed.
\end{abstract}

Keywords: English for the tourism industry; Service encounters; Visitor centre; Giving information; Rapport management; Pragmatic performance

Resumo: Este estudo explora o comportamento dos aprendizes pré-intermediários de inglês para a Indústria do Turismo na fase transacional de um encontro de serviço onde eles precisam realizar uma das tarefas para as quais são treinados: dar informações em um centro de visitantes turísticos. Mais especificamente, este estudo analisa (i) as estratégias com as quais eles dispensam informações turísticas, e (ii) como atendem a aspectos relacionais durante o encontro ou gerenciam relacionamento com os turistas através dessas estratégias e as informações dispensadas. Assim, este estudo pretende lançar luz sobre as habilidades dos alunos antes da instrução em uma área que, embora geralmente incluída nos livros didáticos ESP, parece ter sido negligenciada por praticantes em interlíngua pragmática. A necessidade preliminar de diagnosticar que este trabalho faz pode ser o fundamento sobre o qual a intervenção pedagógica pode ser posteriormente projetada.

Palavras-chave: Inglês para Indústria do Turismo; Encontros de serviço; Centro de visitantes; Informações; Gerenciamento de relacionamento; Desempenho pragmático

\section{Introduction}

Over years of vibrant and fruitful activity, practitioners in interlanguage pragmatics (ILP) have explored a myriad of issues connected with L2 learners' performance. Speech-act realisation has recurrently attracted attention, as attested by the impressive number of studies published in several journals and edited collections (e.g. BARRON, 2003; MARTÍNEZ-FLOR \& USÓ-JUAN, 2010). Although these have targeted pragmalinguistic strategies deployed, cases of transfer from the L1 or problems when accomplishing an enormous variety of verbal actions (see the references in PADILLA CRUZ, 2013a), the emphasis has progressively shifted to production of discourse in various settings (e.g. BARDOVI-HARLIG \& HARTFORD, 2008; BARDOVI-HARLIG \& FÉLIXBRASDEFER, 2016). Researchers have also analysed interpersonal and relational issues in interlanguage pragmatic development (LEECH, 2014, ch. 10) and, obviously, how L2 learners' comprehension skills 
develop across time and their problems when processing contextualised input (COOK \& LIDDICOAT, 2002; LEE, 2010; PADILLA CRUZ, 2013b).

However, learners' behaviour in various service encounters - i.e. those face-to-face or mediated exchanges where services are demanded and supplied (FERNÁNDEZ AMAYA \& HERNÁNDEZ LÓPEZ, 2015, p. 3) - has not received comparable attention. Excessive concern for speech-act realisation, discourse practices, interpersonal aspects and comprehension has probably caused ILP practitioners to neglect that instruction should not be restricted to appropriately performing easily-recognisable momentary individual actions and understanding what is being done. Rather, learners must be trained to successfully engage in longer conversational exchanges serving the purpose of fulfilling diverse goals, where they need to enchain various actions enabling them to momentarily satisfy distinct (non-)material needs (VENTOLA, 2005).

Since the pioneering work by Merritt (1976), service encounters have recently gained momentum. Researchers still focus on specific speech acts like requests, orders or thanks in these encounters (RUZICKOVA, 2007; KUROSHIMA, 2010; RÜEGG, 2014; TAYLOR, 2015), but the scope of analyses has been widened by considering interaction and relational issues in both in-person and mediated encounters (KONG, 1998; ECONOMIDOU-KOGETSIDIS，2005; CARMONA LAVADO \& HERNÁNDEZ LÓPEZ, 2015; MERINO HERNÁNDEZ, 2015). Indeed, service encounters need approaching from an interactive perspective that avoids one-sided descriptions exclusively centred on one of the participants' behaviour or needs (LIND \& SALOMONSON, 2012; FÉLIX-BRASDEFER, 2015).

Typical settings where interaction has been scrutinised in personal service encounters are small/ corner shops, cafés, restaurants or medical consultations (TRAVERSO, 2001; KERBRAT-ORECCHIONI, 2006; KERBRAT-ORECCHIONI \& TRAVERSO， 2008; KUROSHIMA, 2010; LÁZARO GUTIÉRREZ, 2015), to name but some, where researchers have looked into cross-cultural differences (VÉLEZ, 1987; FANT, 1989), pragmatic variation when pluricentric languages are used (PLACENCIA, 2005, 2008; BATALLER, 2015; YATES, 2015), gender differences (FÉLIXBRASDEFER, 2012) or the role of paralanguage (DORAT \& WEBSTER, 2015; LOTH et al., 2015). As regards mediated service encounters, attention has been paid to interaction on e-commerce platforms (IVORRA PÉREZ, 2015; PLACENCIA, 2015) or websites of not-for-profit organisations (BOU FRANCH, 2015) ${ }^{1}$.

Mediated interaction, nevertheless, has thus far been analysed through tools devised for conversational data, so more suitable procedures
In the realm of the hospitality and tourism industry (TI), research on service encounters has mostly been done from marketing-oriented perspectives. Studies have focused on the role of communication (NIKOLICH \& SPARKS, 1995), travellers' satisfaction with hotel encounters (YUNG \& CHAN, 2002), efficient encounter management (JOHNSONS \& MATTSON, 2003) or the effect of employee's intercultural sensitivity on satisfaction (SIZOO et al., 2003). Although some of the studies pointed out above consider interaction in establishments where tourists often go, there is a remarkable paucity of studies from eminently linguistic angles. An exception is maybe one delving into the negotiation tactics exploited by souvenir vendors in an archaeological site (SOLON, 2013). Quite similarly, studies on L2 learners' behaviour in service encounters do not abound in the ESP field. Exceptions are an analysis of how Spanish (pre-)intermediate learners open exchanges at the visitor centre (MARTÍNEZ LÓPEZ \& PADILLA CRUZ, 2012) or another unravelling how those learners would solve hotel guests' problems and carry out service recovery (PADILLA CRUZ, submitted).

This paper seeks to contribute to filling that gap by exploring how Spanish learners of English for the TI (ETI) interact during one of the service encounters likely to occur at a visitor centre. Namely, this paper sets the spotlight on how these learners inform tourists about a destination and its attractions. It aims to analyse the gamut of strategies they deploy when doing so and how they treat tourists while giving them information. Being a pre-instruction study, it will unveil the strategies learners already control and their abilities, but also issues that pedagogical intervention will need to tackle (ISHIHARA \& COHEN, 2010).

\section{Informing tourists at visitor centres}

Visitor centres, or tourist information offices, are public services that supply information and assistance about destinations, attractions and services. They often meet certain requirements in terms of planning, size and layout, and are required to give information in at least two foreign languages. In addition, visitor centres are the venues where hotels or tickets may be booked/ bought and distinct purchases may be made, which gives rise to various service encounters depending on the user's primary goal. This study, nonetheless, only considers encounters where touristic information is supplied.

for digital and digitised discourse still need developing (GARCÉSCONEJOS BLITVICH, 2015). 
Information at visitor centres is a free good for which no payment is demanded ${ }^{2}$. It is dispensed during the transactional phase (LAVER, 1975) of an encounter that brings together at least a tourist agent, who is the informer and adopts the role of service provider, and a user or tourist, who wants/needs information. The encounter normally begins through a brief initial phase where participants acknowledge their presence through routinised greetings (EBSWORTH et al., 1996) and the informer shows responsiveness or readiness to help (ZEITHAML et al., 1990).

At the transactional phase, on which this paper centres, conversational turns and moves accomplish substantive acts that display the participants' intentions and have precise and expected outcomes. Such acts may be attitudinal if participants express positive or negative attitudes to particular states of affairs - e.g. requests (demanding), suggestions (advisory), complaints (dissatisfaction) or apologies (regret) - or informative. Informative acts may simply stick to business and be limited to explanations, comments and opinions, but they may also have a phatic orientation if participants make interlocutor-oriented remarks and disclose personal information (EDMONDSON \& HOUSE, 1981, p. 48-57).

Information must be enough in terms of quantity for it to satisfy tourists' needs, but it must also be objective, unbiased and reliable in terms of completeness and accuracy; it must also be relevant to tourists' interests, and given in an clear, concise and orderly manner. The content of the information and the way it is dispensed are not the only primordial issues; maybe more importantly, tourists must be treated in line with their role and the relationship perceived. This means dealing with face sensitivities, sociality rights and obligations, and interactional goals (SPENCER-OATEY, 2005, 2009). When these are appropriately managed, rapport, or harmonious relations, arises, is maintained or fostered (SPENCER-OATEY, 2005, p. 96).

\section{Power and distance dynamics}

Power relations at a visitor centre are symmetrical. Tourists exert legitimate power (SPENCER-OATEY, 1992): they are the major source of income for the TI and hence make it thrive. They may exhibit their power by beginning the encounter, interrupting informers with questions or deciding when to finish it. Informers, in contrast, have expert power because of their knowledge of the destination, attractions and services. They display this type of power through the information and amount of details they supply (SPENCER-OATEY, 1992).

\footnotetext{
2 This does not exclude that there may be charges for maps, guides or any other material.
}

Informers and tourists often meet at the centre for the first time, so they are not familiar with each other and ignore if they have similar ways of thinking (SPENCEROATEY, 1993). There is social distance, which is furthermore stressed by the institutional context of the encounter, where roles are tightly determined and even physically demarcated by the desk. Tourists may however perceive considerateness, utility or affinity because of age, gender or aspect, which may favour personal revelations contributing to lowering distance (SPENCER-OATEY, 1993).

Distance at the visitor centre tends to supersede and participants treat each other deferentially: interaction, then, takes place in a deference politeness system. If informers perceived that tourists have a higher social status, interaction could proceed in a hierarchical politeness system. However, if they felt a certain similarity, interaction could pursue involvement and hence suggest a solidarity politeness system, where commonality is highlighted (SCOLLON \& WONG-SCOLLON, 1995).

\section{Relational issues}

Along with the transaction at hand, informers must manage rapport efficiently for the encounter to be fruitful and satisfactory. This involves attention to three factors: face sensitivities, sociality rights and obligations, and interactional goals.

Informers must attend to their own and their interlocutor's identity and quality face. The former basically amounts to each individuals' identity, while the latter is shaped by personal characteristics, such as domain-specific competence, reliability and reputation. Informers exhibit, maintain or reinforce their quality face by fulfilling their duties competently. When dispensing information, this involves undertaking tourists' questions and concerns willingly, personalising information, satisfying informational needs clearly and promptly, and fostering, if necessary, appropriate feelings (SCANLAN \& MCPHAIL, 2000). In turn, tourists address their quality face through civilised manners and by making informers feel reliable.

Tourists bring about expectations concerning what they may get access to. These are their sociality rights, among which feature the type of information they may enquire about and considerate treatment from the staff. Those rights, however, are also accompanied by impermissible things, which are their sociality obligations. Among them are requesting services that the centre does not provide or abusing the staff. Informers' sociality obligations are giving quality, satisfactory service, while their sociality rights are not to have their skilfulness, knowledgeability and helpfulness questioned. While some sociality rights and obligations are (culturally) 
determined beforehand, others may be negotiated as the encounter unfolds.

Making the most of their visit to a city by having a great experience usually is tourists' main goal, whose achievement is sometimes contingent on adequate information. Before trips, tourist often search for information in guides or on line, but they may go to a visitor centre in order to complement, check or update it. Being conveniently informed - and maybe concisely, clearly and promptly because of time availability - then, becomes their temporary interactional goal at the centre, while correctly informing tourists becomes that of informers.

Acknowledging and attending to face sensitivities, sociality rights and obligations, and interactional goals involve adopting rapport-maintenance or enhancement orientations, which positively impact on efficiency perceptions and satisfaction. In contrast, intentionally or accidentally disregarding or questioning these factors result in rapport-neglect or challenge orientations, which main ruin an encounter and trigger dissatisfaction (SPENCER-OATEY, 2005, 2009).

\section{The study}

In their professional future, ETI learners will not only need to fulfil several tasks through their L2 competently, but also manage rapport efficiently. This is why this study examines the information they give at a fictitious visitor centre, whether they simply give it or perform other actions, the strategies they deploy when informing tourists and how they manage rapport during this service encounter. The data-collection tool and number of informants render this study a small-scale, exploratory one.

\section{Informants}

24 informants participated at this study. They were Spanish undergraduate students enrolled in the Degree in Tourism at EUSA, a private tertiary-education institution in Seville. On average, they had studied English for 13 years and their level ranged between $\mathrm{A} 2$ and $\mathrm{B} 1^{3}$. Some of them had already had experience at the TI through occasional part-time jobs or internships, but none of them had previous experience at a visitor centre.

\section{Data-collection tool and procedure}

Data were elicited through open/free, mimeticpretending role-plays wherein students assumed the

\footnotetext{
3 The Common European Framework of Reference (CEFR) distinguishes six proficiency levels: A1 (elementary), A2 (beginner/pre-intermediate), B1 (intermediate), B2 (upper-intermediate), C1 (advanced) and C2 (proficiency).
}

roles of informer and tourist (KASPER, 2000; FÉLIXBRASDEFER, 2010). They received prompts describing the setting and their personal attributes, and instructing them to achieve two distinct goals: requesting information about Seville and providing it. While informers were portrayed as individuals in their mid-twenties, three types of tourists were described:

- A dressed-up Norwegian tour-operator wishing to include Seville in a package and eliciting general information about Seville. Position and appearance were aimed to trigger a shift from a deference politeness system to a hierarchical one.

- A retired person planning to spend some days in the city and enquiring about attractions, accommodation and gastronomy. Age-difference intended to make the informer detect distance and to maintain a deference politeness system.

- A German backpacker visiting the city for two days, who asked about attractions, nightlife and accommodation. Slobby appearance, ageproximity and similar interests purported to lead the informer to perceive affinity and to shift from a deference politeness system to a solidarity one.

12 role-plays were recorded, four for each type of tourist, in a classroom at EUSA through Sound Recorder 6.1. The elicited conversations were divided into turns, segmented into moves and transcribed following the notational system used by Spencer-Oatey (2000).

\section{Results}

\section{Pragmalinguistic strategies}

The students acting out as informers produced 90 turns: 15 in the hierarchical politeness system, 28 in the deference system, and 47 in the solidarity one. Role-plays had a mean of 7.5 turns, although those in the hierarchical system contained by far the lowest number: three, two, four and six. In the deference system, students gave information by means of ten, eight and five turns twice, while in the solidarity system they produced nine, four, 12 and 22 turns.

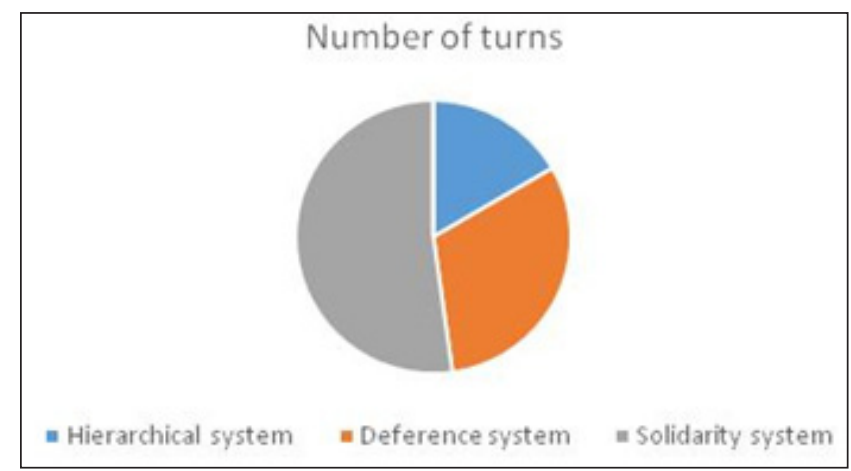


In the hierarchical system, turns comprised 25 moves where students recommended tourists accommodation or various attractions and activities, 12 moves where they expanded on their recommendations by explaining the reasons supporting them, nine moves where they gave personal opinions, one offer to be of further assistance and one request for clarification. In the deference system, turns included 24 moves where students overtly made suggestions, 19 moves where they explained the worthiness of the suggested attractions, eight moves where they expressed personal opinions, one request for repetition, five moves requesting tourists to specify their interests and two moves offering help. Finally, in the solidarity system, students gave advice in 29 moves, explained the reasons for their recommendations in 33 , expressed personal opinions in 18 , enquired about tourists' interests in 11 and even joked in one move.

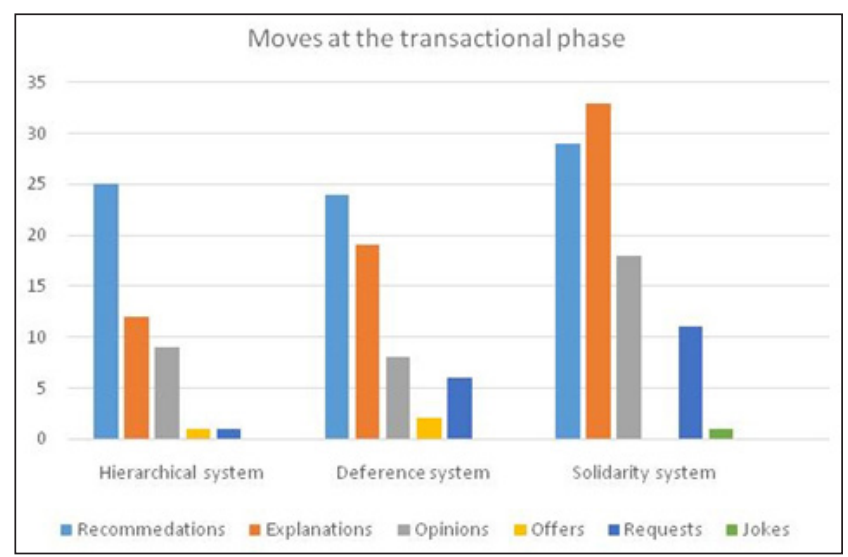

Recommendations in the hierarchical (12.56\%) and deference $(12.06 \%)$ systems exceeded explanations $(6.03 \%, 9.54 \%$, respectively), but in the solidarity system the latter $(16.58 \%)$ overrode the former $(14.57 \%)$. The number of personal opinions expressed in the hierarchical $(4.52 \%)$ and deference $(4.02 \%)$ systems was similar, but they doubled in the solidarity system $(9.04 \%)$. Offers were scarce in the hierarchical $(0.5 \%)$ and deference $(1 \%)$ systems, and non-occurring in the solidarity system. The same was true of requests for specifications or enquiries about the tourists' likes, interests and/or preferences in the hierarchical system $(0.5 \%)$, although they increased in the deference system (3.01\%) and almost doubled in the solidarity system (5.52\%). Finally, although no joke appeared in the hierarchical and deference systems, one appeared in one of the role-plays for the solidarity system $(0.5 \%)$. From this follows that the number of informative $(49.74 \%)$ - i.e. opinions $(17.58 \%)$ and explanations $(32.16 \%)$ - and attitudinal $(48.24 \%)$ - i.e. requests $(9.04 \%)$ and suggestions $(39.19 \%)$ - acts was practically the same at the transactional phase in the three politeness sytems.

Main types of acts at the transactional phase

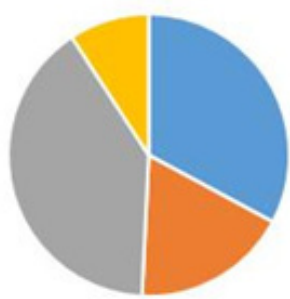

Explanations $=$ Opinions $\|$ Suggestions " Requests

When informing tourists about visits, activities and traditions in the city, students seemed to prefer in 56 of their explanations $(87.5 \%)$ indicative structures with verbs in the third person singular of the present simple. 30 of these structures $(46.87 \%)$ occurred in the hierarchical system (1), $10(15.62 \%)$ in the deference system (2) and $16(25 \%)$ in the solidarity one (3):

(1) [Talking about a monument] eh which is a historical place (.) also in the centre of the city very close to the cathedral and its importance eh comes from the discoverment of America and it was the place well it's now the place where is conserved eh everything related to the discoverment it's (.) it's very important (.) from studies related to the: (.) discoverment of America.

(2) [Talking about a hotel] and it is close to the centre and if you don't want to: (.) to go (walking you can (.) take the underground and it is really: close and: it is just about two or three: stops.

(3) [Talking about the city centre] There are eh $\mathrm{mm}$ eh much (-) mm tapas bar.

In the remaining eight explanations (12.5\%), students also opted for indicative structures, but used the second person singular. This pattern was used twice in the hierarchical (4) and deference (5) systems, while in the solidarity one it was employed four times (6):

(4) [Talking about Seville] where you can find lots of different things.

(5) You take the breakfast in the hotel and maybe then you can visit the city.

(6) In the centre you can you can find a lot of monument (-) interesting for you, you can find the cathedral, quarter Santa Cruz.

$21(60 \%)$ of the 35 opinions expressed contained verbs in the third person singular of the present simple 
or simply were verbless comments. Five of these patterns were found in the hierarchical and deference systems $(7,8)$, whereas 11 appeared in the solidarity system (9):

(7) [Talking about Seville] It's a (.) a great city in [...] but all of them really interesting (.) and enjoyable.

(8) [Talking about a hotel rate] Well, is (.) the price is good for the relation between the quality.

(9) Little plate of with (.) with food but: you can you can, one moment please (.) you can (.) probar? taste? $<<$ you can taste a different $>>$ a different tapas (.) and it's wonderful.

The remaining 14 opinions (40\%) were formulated by means of mental-state verbs $(17.14 \%)$ or structures denoting certainty about the state of affair commented on $(22.85 \%)$. Of these structures, three appeared in the hierarchical system (10), five in the deference system (11) and six in the solidarity one (12):

(10) [When commenting on the two football teams in Seville] I'm quite sure that is eh: (.) the most the most famous one not the best but most of the time is the most acc-accepted in the: another countries $<<\mathrm{I}$ think because of the funny image and also because $>>$ because of having a: difficult history (.) since it was a: team that: was born from the: people that was not accepted to: enter to be to take part into Se-Seville team.

(11) Eh: there are many places to visit but: eh: I think that the most important ones are the cathedral eh: with the: Giralda eh the Alcázar eh: (.) and: many different eh: flamenco shows eh: the Archivo of India and there are many: different and beautiful places that are free for retired people.

(12) [Talking about a disco] Yes I: think that is (.) eight euros: per person more or less (.)

The scarce variety of strategies to accomplish business informative acts contrasted with the number of strategies to give advice about activities. The one occurring in most moves was the mood-derivable structure (51 moves, $65.38 \%$ ): in 35 moves $(44.87 \%)$ epistemic modals were used to allude to the tourists' possibilities (six in the hierarchical system, 12 in the deference system and 17 in the solidarity system) and in 16 moves (20.51\%) deontic modals were chosen to present places or activities as beneficial or desirable (11 in the hierarchical system, three in the deference system and two in the solidarity system):

(13) You can: visit there the cathedral the Archivo de Indias eh eh (.) the Barrio Santa Cruz eh (.) (-) you should have the hotel $<<$ in the::city centre by the cathedral $>>$ eh (.) and you can :: (.) you have very (.) you have (.) several: options eh like the EME Fussion and the: the Los Seises (.)

(14) There are many different dishes you can: enjoy: in this country not $<<$ just in Seville because the gastronomy of the country is really good $>>$

(15) You should visit the cathedral eh: (.) because of the importance of the historical importance and also of the:: religious importance.

(16) You shouldn't miss eh ah Magic Island (.) a very important amusement park in Andalucía eh it is very funny if you want to have a good time eh

(17) OK, so how how I have eh (.) as I have told you your clients could visit the different monuments eh: (.) thee amusement park or they could even have a walk in Seville eh (.)

The second most frequent strategy to recommend was explicit performative verbs. These occurred in 19 moves $(24.35 \%)$ and the verbs employed were 'advise' (two examples in the deference system, and one in both the hierarchical and solidarity system; $5.12 \%$ in total), 'suggest' (one example in both the hierarchical and deference systems; $2.56 \%$ in total) or 'recommend' (five examples in the hierarchical system and four examples in both the deference and solidarity systems; $16.66 \%$ in total):

(18) Umm (.) well I advise you to take the: half (.) board

(19) Ok; eh I (.) I (-) I recommend you to go to to: to the city centre.

(20) I suggest that you should stay in some hotels in the city centre for example the Alfonso the Alfonso XIII or NH hotel.

Additionally, there were other less frequent strategies. In the solidarity politeness system, students used conditional structures (21) in four moves (5.12\%) and conventionalised indirect forms (22) in three moves $(3.84 \%)$. In turn, in the deference system one of the students employed a more elaborate formula (23):

(21) Sure (.) if I were you I : I <<if I were you >> I would go to: Antique (.) it's the: most important disco: in Seville and it's beautiful, and (???) there are a lot of discos.

(22) Eh: the hotel? Why don't you go: to: (.) hostal?

(23) Then the first eh: $<<$ recommendation I have to give you is $>>$ to carry eh: light clothes and comfortable clothes so so you: won't have any problem there?

Requests were also made in different manners. The only request for repetition, which appeared in a role-play 
in the deference system, was formulated by means of a conventionally indirect form (24). In contrast, requests for clarifications or additional enquiries about the tourists' interests or intentions, which appeared in 13 moves in the solidarity system $(72.2 \%)$ and in four in the deference one $(22.2 \%)$, were made by means of diverse wh- and yes-no questions:

(24) Sorry can you repeat please?

(25) Eh mm (-) do you wanna eh (-) visit just the centre??

(26) A:nd what kind of food $<<$ do you prefer $>>$ ?

(27) Are you interested in anything else? That I could...

(28) Sure do you li do you want eh to go to museum or centre histo historic?? Of Seville?

Finally, the transactional phase of the encounter included other acts like offering and joking. Offers of assistance occurred in the deference and hierarchical systems and were worded by means of modals indicating ability, willingness and readiness to perform the action referred to (29). On the other hand, joking only appeared in a role-play in the solidarity system after the tourist had enquired about places to sleep and pointed out that he could not afford to spend much in accommodation (30):

(29) And it I can eh give you a map and I can (.) underline you the best monuments (.) and you can ask there how to arrive to: any: place.

(30) (laughs) In the street; eh: (.) well you (.) like I I (.) told you before you can go to a youth hostel, $<<$ this is the best option but if you prefer $>>$ to (.) to sleep in the street (.) ehh I if I were you I would go to a: (.) to a park near the city centre as it could be more (????) for you you know, that in the (.) neighbourhoods around the the city centre.

The strategies at the transactional phase of the encounter are presented in the following graphic:

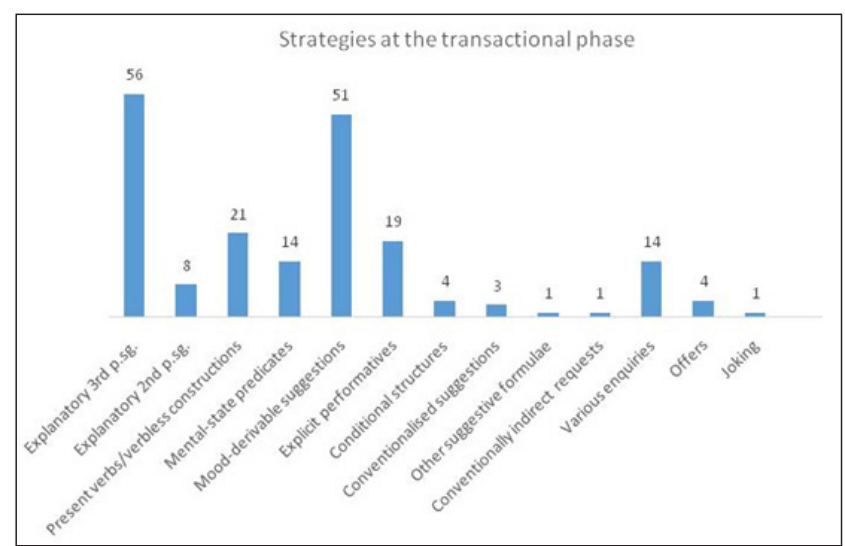

\section{Rapport management}

Overall, most of the Spanish A2-B1 ETI learners participating at this study seemed to manage rapport efficiently when giving information. In both the hierarchical and deference systems, seven students duly attended to their own quality face and sociality obligations, and the tourists' quality face and sociality rights by promptly making suggestions and providing information that was concise, clear and well-structured. Thus, they adopted a rapport-maintenance orientation throughout the encounters. Present simple constructions in the third person singular enabled students to highlight the objectivity of information, as well as to present some of their opinions objectively. Mental-state predicates, in contrast, underlined the subjectivity of other opinions and maybe suggested tentativeness.

It was remarkable that in the hierarchical system deontic modals were preferred when giving advice, which might have stemmed from the need to treat tourists deferentially because of their status. Those modals enabled students to address the tourists' quality face. Deferential treatment was also evident in the mitigation of some suggestions through hedges such as "if you want", which made it clear that the advice was not meant to curtail freedom of action. Epistemic modals alluding to possibilities, in turn, made the other suggestions sound tentative, which avoided imposing over the tourist:

(31) Ok, so: I recommend you eh:: some activities like (.) eh visit: different monuments (.) like (.) eh Giralda: Torre del Oro:: eh:: the: different museums [...] you should go to the María Luisa's park and there is a very important museum (-) [...] I would recommend you some hotels if you want (.) eh::: there are eh: next to the cathedral there is a new hotel eh:: which is really good (.) is a five star hotel or::: if you want; there is another one in la Macarena (.) Trip Macarena (.) which is near the city centre

In the deference system, in contrast, recommendations exhibited preference for mood-derivable constructions with epistemic modals, which quadrupled those with deontic modals. This suggests that students felt no need to address tourists' quality face by hinting higher status. Rather, they opted for tentativeness and presented recommendations as options:

(32) $[\ldots]$ you can: visit there the cathedral the Archivo de Indias eh eh (.) the Barrio Santa Cruz eh (.) (-) [...] eh (.) and you can :: (.) you have very (.) you have (.) several: options eh like the EME Fussion and the: the Los Seises (.) $<<$ I recommend you Los Seises 
because the EME Fussion>> is very: new and very modern to: to you [...] and (.) you: you also have $\mathrm{mm}$ several $\mathrm{mm}$ ways $\mathrm{mm}$ for transport like the: (.) train view? the: (.) taxis (.) buses and horse cars? (.) and (.) and $<<$ you can also $>>$ eh (-) see (-) see the city eh on the sightseeing tour bus.

Explicit performatives when advising tourists in both systems might have been triggered by the students' desire to reinforce their quality face as informers by presenting themselves as knowledgeable individuals who are capable of selecting the products that best suit tourists. Additionally, in the deference system the desire to address their own quality face and to keep distance resulted in the more sophisticated form to recommend (23) and in the conventionally indirect question (24) when asking a tourist to repeat. Attention to quality face also explains the offers made in both the hierarchical and deference systems, wherewith students showed willingness to help and readiness to be of further assistance (29).

Only in one role-play in the hierarchical system did a student give an excessive amount of information. Awareness of the tourist's influential position and concern for his sociality rights led the student to elaborate on his recommendations by adding explanations and details. As a result, the student monopolised the encounter through rather long turns which, nevertheless, enabled him to attend to his own quality face:

$<<$ First of all I would like to tell you that Seville it's $>>$ a (.) it's a (.) a great city in (.) where you can find lots of different things (.) but all of them really interesting (.) and enjoyable; eh (.) you should visit the cathedral eh : (.) because of the importance of the historical importance and also of the:: religious importance; it's nice and apart from being one of the: (.) biggest in all over the world; eh (-) [coughs] you could also visit Archivo de Indias eh which is a historical place (.) also in the centre of the city very close to the cathedral and its importance eh comes from the discoverment of America and it was the place well it's now the place where is conserved eh everything related to the discoverment it's (.) it's very important (.) from studies related to the: (.) discoverment of America (.) apart from that; there is also (.) lots of things for example one of the most representative is the: (.) barrio Santa Cruz; which is a: place eh famous for the: for being eh (.) the typical (.) the typical quarter of the Jewish people (.) in ancient times and it's full of histories and also: eh: of: (.) of representative eh: bars and (.) streets eh: (.) unique in all in all over the world $<<$ for example there is a $>>$ street which is so narrow that you can you can touch both: both part of it with your with your own hand; eh: apart from that; I would like also to speak about [...]
One of the students interacting in the solidarity system chiefly maintained rapport by appropriately treating the tourist and limiting his turns to plainly informing clearly, objectively, concisely and in an organised way. In contrast, the higher number of turns in the other three role-plays reveals that the other students adopted a more interactive orientation by enquiring tourists about their interests. Their questions $(28,34-37)$ aimed at customising information, which not only enabled them to attend to their own quality face and sociality obligations as informers, but also to address tourists' quality face and sociality rights, and to imply true concern for their needs:

(34) Ok ehh is you first time in Seville?

(35) Ok are you going with your friends?

(36) How many people?

(37) Eh: what are you seeking for?

Attention to quality face and sociality rights and obligations was also evident in the higher number of explanations, where students voiced a higher number of opinions. Although some of these were objectively presented (12), others were more personal $(9,38)$, which suggests that students adopted a more interpersonal, phatic orientation by revealing their preferences and tastes. Perceptions of affinity in terms of age and interests would have warranted this behaviour, wherewith students sought to achieve involvement with tourists. Involvement was also sought through the conditional structures in recommendations $(21,39)$ and the joke $(30)$, wherewith students hinted common interests, values and viewpoints:

(38) It's the:most important disco: in Seville and it's beautiful, and (???) there are a lot of discos, (.) where you can find different type of music and $<<$ different type of people $>>$ but I like Antique and: (.) if you want to: go to: small bar you can: you can: you can: go to centre of Seville where you can find $\mathrm{mm}$ : a pubs? it's like a disco mo but more: small? and they closed mm early?

(39) Eh ok (.) party? (laughs) yes sure? you can find parties for all sides eh in Seville there are a culture (.) eh in that the people lovely love the street and (.) if I were you I would go to a bottellón (laughs) the botellón is where the young people eh quedan? (.) get (.) together for drinking and drinking and drinking and before they go to disco (.) and dancing.

It is noteworthy that, when recommending, students preferred mood-derivable constructions containing epistemic modals over those containing deontic ones, which could show no need for deferential treatment. Moreover, conventionally indirect forms whereby 
students asked about the reasons why tourists would not do something $(22,40)$, which somehow insinuate that interlocutors cooperate, only appeared in role-plays in this system:

\section{(40) Why don't you go to: Alameda?}

As in the hierarchical and deference systems, students in the solidarity system efficiently managed rapport and contributed to achieving the interactional goals of the encounter. However, their questions and attempts at identifying themselves with tourists and hinting of commonality and cooperation could also indicate that they strove to shift from a mere rapport-maintenance orientation to a rapport-enhancement one.

Rapport-neglect orientations were not observed in the role-plays in the solidarity and deference systems. Nevertheless, in a role-play in the hierarchical system the student quite surprisingly did not comply with the tourist's requests: instead of supplying information, the student simply directed the tourist to enquire elsewhere. This could be interpreted as disregard of rapport and might have affected satisfaction considerably:

(41) Well (.) let me tell you that Sevilla is a (laughs) is a (.) city (.) a gorgeous city where you can find so many different eh kinds of tourism so you can eh maybe organise different package for your tra travel agency? or tour operator? and you eh perfectly can talk eh with the travel agencies and maybe eh make some arrangements some eh (.) to: I don't know to see what (.) yeah (.) cultural heritage or $<<$ activities and services that they can offer you $>>$ or maybe (.) eh plan for you that you are staying there (.) and you cannot plan it here (.) so I recommend you to talk with them and maybe $\mathrm{mm}$ (.) eh $<<$ to see a little bit about the city $>>$ to (.) sight sight sightseeing?? the city? and then $<<$ you can see that we have a lot of cultural heritage $>>$ and gastronomy folklore and all that stuff and that could be very interesting for your eh pac package, tour.

Finally, rapport-challenging behaviours were not noticed in the hierarchical and solidarity systems either. In contrast, in two of the role-plays in the deference system what one of the students said when recommending a hotel (42) and not giving an estimate of a hotel rate (43) could have threatened rapport, even if momentarily, and called for subsequent compensation:

$<<$ I recommend you Los Seises because the EME Fussion $>>$ is very: new and very modern to: to you. It's a (.) four star (.) hotel.
By pointing out that a particular hotel could be "very new and very modern" to somebody, the first student appeared to ignore the tourist's identity face. In turn, by inviting a conversational implicature - i.e. that a hotel could be expensive - the second student seemed to not have respected the tourist's right for information and to have neglected his obligation to give it. The latter behaviour, however, could also have been motivated by lack of precise information, so, had that been the case, it would have counted as an attempt by the student to save his quality face.

\section{Concluding remarks}

Performance analysis prior to instruction helps ascertain not only familiarity with pragmalinguistic strategies, but also awareness of expected, acceptable and unacceptable behaviours in particular settings (ISHIHARA \& COHEN, 2010). In a sensitive area like service encounters, where what is at stake is not only access to products or services, but also the participants' identities, professionalism and relationships, what is said and done when providing a service or product may hinder or contribute to the attainment of success and satisfaction, as well as projection of a good image as workers.

Data examination in this study reveals, for instance, that instruction at a(n) (pre-)intermediate level could probably endeavour at equipping learners with a wider repertoire of strategies deployable at visitor centres: presupposing tourists' intentions or interests, or exhibiting optimism when recommending; distinct tactics to attenuate opinions; increasing interest when explaining, etc. Even if the strategies already available to learners enabled a moderately acceptable performance, a wider range of tactics to dispense information, express opinions or give advice would significantly benefit learners' pragmatic skills and quality face as informers, and contribute to satisfactory management of sociality rights and obligations.

This survey also suggests that pedagogical intervention in informational tasks at visitor centres needs not excessively concentrate on the actions whereby learners can maintain or enhance their quality face as informers, or what appropriate management of sociality rights and obligations requires. Common sense, previous experience at these centres or at similar service encounters, or training in other service encounters may have facilitated their efficiency. This should not exclude, however, that learners are warned about the potentially negative consequences of some behaviours - provided their intention is not to undermine rapport - or about attitudes and orientations likely to foster rapport. 
ETI teachers' guides do not usually alert to these issues and students' books only include succinct protocols for action or exposure to a limited amount of examples through written dialogues or audio-visual support (PADILLA CRUZ, submitted). Quite often, emphasis is still placed on morphosyntax and specialised vocabulary, so reliance on existing pedagogical materials does not guarantee the effectiveness of instruction in service encounters. Detection of strengths, weaknesses and deficits through interlanguage pragmatic research may assist ETI instructors to overcome lacunae in available materials and tailor-suit intervention. This may certainly lay the foundations for success at future professional tasks whose fulfilment is contingent on supply of services and products, but more importantly, on attention to relational issues, to which pragmatics is vital.

\section{References}

BARDOVI-HARLIG, Kathleen; FÉLIX-BRASDEFER, J. César (Ed.). Pragmatics and Language Learning. v. 14. Honolulu: University of Hawai'i, National Foreign Language Resource Center, 2016.

BARDOVI-HARLIG, Kathleen; HARTFORD, Beverly S. Interlanguage Pragmatics. Exploring Institutional Talk. London: Routledge, 2008.

BARRON, Anne. Acquisition in Interlanguage Pragmatics. Learning How to Do Things with Words in a Study Abroad Context. Amsterdam: John Benjamins, 2003.

BATALLER, Rebeca. Pragmatic variation in the performance of requests: A comparative study of service encounters in Valencia and Granada (Spain). In: HERNÁNDEZ LÓPEZ, María de la O; FERNÁNDEZ AMAYA, Lucía (Ed.). A Multidisciplinary Approach to Service Encounters. v. 14, Leiden: Brill, 2015. p. 113-137.

BOU FRANCH, Patricia. The genre of web-mediated service encounters in not-for-profit organizations: Cross-cultural study. In: HERNÁNDEZ LÓPEZ, María de la O; FERNÁNDEZ AMAYA, Lucía (Ed.). A Multidisciplinary Approach to Service Encounters. v. 14, Leiden: Brill, 2015. p. 65-83.

CARMONA LAVADO, Antonio; HERNÁNDEZ LÓPEZ, María de la $\mathrm{O}$. Customer perceptions of politeness as a differentiating element in Spanish restaurants encounters. In: HERNÁNDEZ LÓPEZ, María de la O; FERNÁNDEZ AMAYA, Lucía (Ed.). A Multidisciplinary Approach to Service Encounters. v. 14, Leiden: Brill, 2015. p. 87-112.

COOK, Misty; LIDDICOAT, Anthony. The development of comprehension in interlanguage pragmatics: The case of request strategies in English. Australian Review of Applied Linguistics, v. 25 , n. 1, p. 19-39, 2002.

DORAT, Sundaram; WEBSTER, Cynthia. The role of nonverbal communication in service encounters. In: HERNÁNDEZ LÓPEZ, María de la O; FERNÁNDEZ AMAYA, Lucía (Ed.). A Multidisciplinary Approach to Service Encounters. v. 14, Leiden: Brill, 2015. p. 211-228.
EBSWORTH, Miriam E.; BODMAN, Jean W.; CARPENTER, Mary. Cross-cultural realization of greetings in American English. In: GASS, Susan M.; NEU, Joyce (Ed.). Speech Acts across Cultures: Challenges to Communication in a Second Language. Berlin: Mouton de Gruyter, 1996. p. 89-107.

ECONOMIDOU-KOGETSIDIS, Maria. "Yes, tell me please, what time is the midday flight from Athens arriving?": Telephone service encounters and politeness. Intercultural Pragmatics, v. 2, n. 3, p. 253-273, 2005.

EDMONDSON, Willis; HOUSE, Juliane. Let's Talk and Talk about It. München: Urban \& Schwarzenberg, 1981.

FANT, Lars. Cultural mismatch in conversation: Spanish and Scandinavian communicative behavior in negotiation settings. Hermes. Journal of Language and Communication in Business, n. 3, p. 247-265, 1989.

FÉLIX-BRASDEFER, J. César. Data collection methods in speech act performance. DCTs, role plays, and verbal reports. In: MARTÍNEZ-FLOR, Alicia; USÓ-JUAN, Esther (Ed.). Speech Act Performance. Theoretical, Empirical and Methodological Issues. Amsterdam: John Benjamins, 2010. p. 41-56.

FÉLIX-BRASDEFER, J. César. Pragmatic variation by gender in market service encounters in Mexico. In: FÉLIX-BRASDEFER, J. César; KOIKE, Dale A. (Ed.). Pragmatic Variation in First and Second Language Contexts. Methodological Issues. Amsterdam: John Benjamins, 2012. p. 17-48.

FÉLIX-BRASDEFER, J. César. The Language of Service Encounters: A Pragmatic-Discursive Approach. Cambridge: Cambridge University Press, 2015.

FERNÁNDEZ AMAYA, Lucía; HERNÁNDEZ LÓPEZ, María de la O. Service encounters and communication: Why a multidisciplinary approach? In: HERNÁNDEZ LÓPEZ, María de la O; FERNÁNDEZ AMAYA, Lucía (Ed.). A Multidisciplinary Approach to Service Encounters. Leiden: Brill, 2015. p. 3-12.

FINK, Lisa N.; FÉLIX-BRASDEFER, J. César. Pragmalinguistic variation and barista perceptions in US café service encounters. In: BEECHING, Kate; WOODFIELD, Helen (Ed.). Researching Sociopragmatic Variability. Perspectives from Variational, Interlanguage and Contrastive Pragmatics. Basingstoke: Palgrave Macmillan, 2015. p. 19-48.

GARCÉS-CONEJOS BLITVICH, Pilar. Setting the linguistics research agenda for the e-service encounters genre: natively digital versus digitized perspectives. In: HERNÁNDEZ LÓPEZ, María de la O; FERNÁNDEZ AMAYA, Lucía (Ed.). A Multidisciplinary Approach to Service Encounters. Leiden: Brill, 2015. p. 15-36.

IVORRA-PÉREZ, Francisco Miguel. The impact of cultural dimensions on the engagement markers of Spanish, British and US toy selling websites. In: HERNÁNDEZ LÓPEZ, María de la O; FERNÁNDEZ AMAYA, Lucía (Ed.). A Multidisciplinary Approach to Service Encounters. v. 14, Leiden: Brill, 2015. p. 141-163.

ISHIHARA, Noriko; COHEN, Andrew D. Teaching and Learning Pragmatics. Where Language and Culture Meet. Harlow: Pearson, 2010. 
JOHNS, Nick; MATTSSON, Jan. Managing the service encounters in tourism. In: KUSLUVAN, Salih (Ed.). Managing Employee Attitudes and Behaviors in the Tourism and Hospitality Industry. New York: Nova Science Publishers, 2003. p. 173-200.

KASPER, Gabriele. Data collection in pragmatics research. In: SPENCER-OATEY, Helen (Ed.). Culturally Speaking. Managing Rapport through Talk across Cultures. London: Continuum, 2000. p. 316-341.

KERBRAT-ORECCHIONI, Catherine. Politeness in small shops in France. Journal of Politeness Research. Language, Behaviour, Culture, v. 2, n. 1, p. 79-103, 2006.

KERBRAT-ORECCHIONI, Catherine; TRAVERSO, Veronica. Presentation. In: Les interactions en site commercial: Invariants et variations. Lyon: Ens Éditions, 2008. p. 7-42.

KONG, Kenneth C. C. Politeness of service encounters in Hong Kong. Pragmatics, v. 8, n. 4, p. 555-575, 1998.

KUROSHIMA, Satomi. Another look at the service encounter: Progressivity, intersubjectivity, and trust in a Japanese sushi restaurant. Journal of Pragmatics, v. 42, n. 3, p. 853-869, 2010

LAVER, John. Communicative functions of phatic communion. In: KENDON, Adam; HARRIS, Richard M.; KEY, Mary Ritchie (Ed.). Organisation of Behaviour in Face-to-face Interaction. The Hague: Mouton, 1975. p. 215-238.

LÁZARO GUTIÉRREZ, Raquel. The evolution of communication with foreign population in medical settings in Spain. In: HERNÁNDEZ LÓPEZ, María de la O; FERNÁNDEZ AMAYA, Lucía (Ed.). A Multidisciplinary Approach to Service Encounters. Leiden: Brill, 2015. p. 164-187.

LEE, Cynthia. An exploratory study of the interlanguage pragmatic comprehension of young learners of English. Pragmatics, v. 20, n. 3, p. 343-373, 2010.

LEECH, Geoffrey. The Pragmatics of Politeness. Oxford: Oxford University Press, 2014.

LIND, Mikael; SALOMONSON, Nicklas. Using pragmatic concepts for exploring interactivity in service encounters. Systems, Signs \& Actions. An International Journal on Information Technology, Action, Communication and Workpractices, v. 7, n. 2, p. 205-226, 2013.

LOTH, Sebastian; HUTH, Kerstin; DE RUITER, Jan. Seeking attention: Testing a model of initiating service interactions. In: HERNÁNDEZ LÓPEZ, María de la O; FERNÁNDEZ AMAYA, Lucía (Ed.). A Multidisciplinary Approach to Service Encounters. Leiden: Brill, 2015. p. 229-247.

MARTÍNEZ-FLOR, Alicia; USÓ-JUAN, Esther (Ed.). Speech Act Performance. Theoretical, Empirical and Methodological Issues. Amsterdam: John Benjamins, 2010.

MARTÍNEZ LÓPEZ, Nuria; PADILLA CRUZ, Manuel. Rapport management by Spanish learners of English as an L2 at the opening phase of interaction in the tourist information office: A pragmatic analysis. In: ELORZA, Izaskun et al. (Ed.). Empiricism and Analytical Tools for $21^{\text {st }}$ Applied Linguistics. Salamanca: Ediciones Universidad de Salamanca, 2012. p. 833-846.
MERINO HERNÁNDEZ, Laura M. Tianguis Friki: Intracultural pragmatic variation of e-service encounters in a northern Mexican community. IULC Working Papers, v. 15, n. 1, p. 159-180, 2015.

MERRITT, Marilyn. On questions following questions in service encounters. Language in Society, v. 5, n. 3, p. 315-357, 1976.

NIKOLICH, M. A.; SPARKS, B. A. The Hospitality Service Encounter: The Role of Communication. Journal of Hospitality \& Tourism Research, v. 19, n. 2, p. 43-56, 1995.

PADILLA CRUZ, Manuel. Understanding and overcoming pragmatic failure in intercultural communication: From focus on speakers to focus on hearers. International Review of Applied Linguistics in Language Teaching, v. 51, n. 1, p. 23-54, 2013a.

PADILLA CRUZ, Manuel. Metapsychological awareness of comprehension and epistemic vigilance of L2 communication in interlanguage pragmatic development. Journal of Pragmatics, v. 59, n. A, p. 117-135, 2013 b.

PADILLA CRUZ, Manuel. Restoring satisfaction at hotels: Pragmatic performance and rapport management by Spanish learners of English for the Tourism Industry. Submitted.

PLACENCIA, María E. Pragmatic variation in corner store interactions in Quito and Madrid. Hispania, v. 88, n. 3, p. 583-598, 2005.

PLACENCIA, María E. Requests in corner shop transactions in Ecuadorian Andean and Coastal Spanish. In: SCHNEIDER, Klaus; BARRON, Anne (Ed.). Variational Pragmatics: A Focus on Regional Varieties in Pluricentric Languages. Amsterdam: John Benjamins, 2008. p. 307-332.

PLACENCIA, María E. Address forms and relational work in e-commerce: The case of service encounter interactions in MercadoLibre Ecuador. In: HERNÁNDEZ LÓPEZ, María de la O; FERNÁNDEZ AMAYA, Lucía (Ed.). A Multidisciplinary Approach to Service Encounters. Leiden: Brill, 2015. p.37-64.

RUZICKOVA, Elena. Customer requests in Cuban Spanish: Realization patterns and politeness strategies in service encounters. In: PLACENCIA, María E.; GARCÍA, Carmen (Ed.). Research on Politeness in the Spanish-Speaking World. Mahwah, NJ: Lawrence Earlbaum Associates, 2007. p. 213-244.

RÜEGG, Larssyn. Thanks responses in three socio-economic settings: A variational pragmatics approach. Journal of Pragmatics, v. 71, p. 17-30, 2014.

SCANLAN, Laurel; McPHAIL, Janelle. Forming service relationships with hotel business travelers: The critical attributes to improve retention. Journal of Hospitality \& Tourism Research, v. 24, n. 4, p. 491-513, 2000.

SCOLLON, Ron; WONG-SCOLLON, Suzanne. Intercultural Communication. A Discourse Approach. Oxford: Blackwell, 1995.

SIZOO, Steve; ISKAT, Wilfried; PLANK, Richard E.; SERRIE, Hendrick. Cross-cultural service encounters in the hospitality industry and the effect of intercultural sensitivity on employee performance. International Journal of Hospitality \& Tourism Administration, v. 4, n. 2, p.61-77, 2003. 
SOLON, Megan. Cross-cultural negotiation: Touristic service encounters in Yucatán, Mexico. In: HOWE, Chad et al. (Ed.). Selected Proceedings of the 15th Hispanic Linguistics Symposium. Somerville, MA: Cascadilla Proceedings Project, 2013. p. 252-268.

SPENCER-OATEY, Helen. Cross-cultural politeness: British and Chinese conceptions of the tutor-student relationship. $\mathrm{PhD}$ dissertation, Lancaster University, 1992.

SPENCER-OATEY, Helen. Conceptions of social relations and pragmatics. Journal of Pragmatics, v. 20, n. 1, p. 27-47, 1993.

SPENCER-OATEY, Helen. Culturally Speaking. Managing Rapport in Talk across Cultures. London: Continuum, 2000.

SPENCER-OATEY, Helen. (Im)Politeness, face and perceptions of rapport: Unpackaging their bases and interrelationships. Journal of Politeness Research. Language, Behaviour and Culture, v. 1, n. 1, p.95-119, 2005.

SPENCER-OATEY, Helen. Face, identity and interactional goals. In: BARGIELA, Francesca; HAUGH, Michael (Ed.). Face, Communication and Social Interaction. London: Equinox, 2009. p. 137-154.

TRAVERSO, Veronica. Syrian service encounters: A case of shifting strategies within verbal exchange. Pragmatics, v. 11, n. 4, p. 421-444, 2001.
TAYLOR, Jenna L. I need a coffee: Pragmalinguistic variation of Starbucks service encounter requests according to interaction modality. IULC Working Papers, v. 15, n. 1, p. 33-61, 2015.

VÉLEZ, Jorge A. Contrasts in language use: A conversational and ethnographic analysis of service encounters in Austin and San Juan. PhD dissertation, The University of Texas at Austin, 1987.

VENTOLA, Eija. Revisiting service encounters genre - some reflections. Folia Linguistica, v. 39, n. 1/2, p. 19-43, 2005.

YATES, Allison B. Pragmatic variation in service encounters in Buenos Aires, Argentina. IULC Working Papers, v. 15, n. 1, p. 128-158, 2015.

YUN, Evita; CHAN, Andrew. Business traveler satisfaction with hotel service encounters. Journal of Travel \& Tourism Marketing, v. 11, n. 4, p. 29-41, 2002.

ZEITHAML, Valarie; PARASURAMAN, A.; BERRY, Leonard L. Delivering Quality Service. New York: The Free Press, 1990.

Recebido: 11 de fevereiro de 2017

Aprovado: 12 de março de 2017

Contato:

Manuel Padilla Cruz<mpadillacruz@us.es>

Nuria Martínez López <nuria.martinez-lopez@ncl.ac.uk> 